\title{
Negócio simples
}

Livro apresenta o modelo de negócios da rede de supermercados alemã ALDI, que insiste na simplicidade como estratégia. Em um momento em que as empresas preocupam-se com a gestão da complexidade, o modelo da ALDI pode servir como interessante, embora questionável, contraponto.

\section{por Lígia K. Ishida}

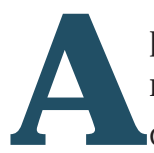

pesar de ainda pouco presentes no Brasil, os supermercados de descontos estão causando uma importante transformação no varejo mundial. Talvez o principal deles, o alemão ALDI vem provando até mesmo aos mais céticos que a filosofia de preços baixos, quando levada realmente a sério, pode trazer resultados invejáveis. É de fato impressionante que uma empresa como essa, nascida em meio à profunda crise da Alemanha do pós-guerra, tenha hoje força suficiente para perturbar gigantes varejistas como a norte-americana Wal Mart. $O$ livro de Dieter Brandes, ex-CEO da rede, procura resumir o sucesso do ALDI em 11 pontos principais, todos eles de certa forma atrelados à premissa básica da rede - a simplicidade em todos os aspectos.

É interessante notar que o conceito que transformou a rede em um incontestável sucesso surgiu por acaso. As muitas restrições orçamentárias não deram aos irmãos Theo eKarl Albrecht outra opção senão reduzir o sortimento de produtos de seu pequeno mercado, mantendo apenas itens básicos do dia-a-dia. Dada essa limitação, os preços baixos também eram obrigatórios. Com o tempo, porém, notou-se que os resultad os da empresa eram bastante satisfatórios e que, portanto, não havia nenhuma razão para modificar tal estratégia.

0 primeiro passo para assimilar a filosofia do ALDI é compreender que simplicidade não é necessariamente sinônimo de baixa qualidade. Ser simples é saber rapidamente distinguir entre 0 essencial e o supérfluo para poder renunciar com segurança a tudo o que não for verdadeiramente importante para 0 consumidor; é aperfeiçoar diariamente os detal hes, porém somente aqueles que realmente fazem diferença; é evitar o desperdício em toda e qualquer situação, seja nas lojas, seja na administração. Seguindo tal raciocínio, o ALDI aposta em lojas sem grandes confortos - as sacolas plásticas, por exemplo, são cobradas à parte -, investe pouco dinheiro em propaganda, mantém seu sortimento em cerca de 600 itens e, conseqüentemente, sempre consegue entregar ao consumidor o produto certo ao preço mais baixo possível.

Além disso, afirma o autor, o foco de qualquer empresa deve ser sempre 
a satisfação do consumidor - 0 aumento de receita será simplesmente uma conseqüência natural. N ão é necessário investir pesadamente em pesquisas ou no desenvolvimento de teorias revolucionárias para entender e prever 0 comportamento do consumidor. Brandes afirma que a maioria das grandes empresas costuma empregar uma infinidade de números e cál culos no apoio às decisões estratégicas. Também é comum o uso de ferramentas e técnicas consagradas. Segundo o autor, trata-se de um pensamento altamente complexo para um problema bastante simples: a verdadeira preocupação com o consumidor. A impressão que se tem é que todos esses dados funcionam como uma espécie de proteção para a empresa, que serão utilizados para justificar uma decisão equivocada ou um eventual fracasso. No ALDI, os gerentes não mergulham em um mar de números; em vez disso, visitam as lojas e se colocam no lugar do consumidor para entender quais são suas reais necessidades.

A rede também acredita que a confiança é um importante fator redutor de complexidadee, por isso, procura sempre fortalecer seu relacionamento não apenas com os clientes, mas também com funcionários e fornecedores. A empresa se esforça para sempre adotar uma postura justa, pois acredita que dessa forma o bom relacionamento estará garantido por um longo período, trazendo benefícios para ambas as partes.

Não se pode negar que a traj etória do ALDI tem sido de fato bastante admirável e serve de inspiração para empresas de todos os segmentos. Porém, por mais glorioso que tenha sido o passado de qualquer organização, ele nunca será suficiente para garantir a continuidade do sucesso. Há quem diga que, se o ALDI não aumentar 0 número de itens comercializad os, o fim estará próximo, afirmação que também parece ser um tanto quanto radical. De qualquer forma, o crescimento de concorrentes como o Lidl exige que 0 ALDI ao menos se disponha a olhar para os lados antes de definir o rumo que irá tomar.

Lígia K. Ishida

Publicitária

E-mail: ligiaishida@gmail.com

\section{Ser simples é saber rapidamente distinguir entre 0 essencial e 0 supérfluo para poder renunciar com segurança a tudo o que não for verdadeiramente importante para o consumidor; é aperfeiçoar diariamente os detalhes, porém somente aqueles que realmente fazem a diferença; é evitar o desperdício em toda e qualquer situação.}

